\title{
Primary intradural extramedullary ependymoma: report of two cases and review of the literature
}

\section{Pierwotny wyściótczak wewnq̨trztwardówkowy i zewnątrzrdzeniowy: opis dwóch przypadków i przegląd piśmiennictwa}

Pradipta Tripathy, Debahuti Mohapatra, Satya Mohapatra

Institute of Medical Sciences \& SUM Hospital, Bhubaneswar, Odisha, India

Neurologia i Neurochirurgia Polska 201 1; 45, 4: 397-401

\begin{abstract}
Primary intradural extramedullary ependymomas are very rare. They are called primary in this location as they do not have any connection with the central nervous system. They usually develop from an ectopic ependymal cell nest. To the best of our knowledge, only 10 cases have been described in the literature. We report two cases of large sausage-shaped intradural extramedullary ependymoma in the lumbosacral area.
\end{abstract}

Key words: primary, intradural, extramedullary, ependymoma.

\section{Introduction}

Tumours of the spinal cord are unusual. In a gene ral hospital, only $5 \%$ of spinal tumours are intra medullary, $40 \%$ are intradural extramedullary, and $55 \%$ are extradural [1]. Ependymoma typically has an intramedullary location and represents $60 \%$ of intramedullary tumours [1]. Ependymoma is a glial tu mour known to arise from the central nervous system [1]. Primary intradural extramedullary ependymomas

\section{Streszczenie}

Pierwotny wyściółczak wewnątrztwardówkowy i zewnątrzrdzeniowy jest dużą rzadkością. Określenie „pierwotny” odnosi się do braku łączności tych guzów z ośrodkowym układem nerwowym. Guzy te wywodzą się zwykle z ektopowych gniazd komórek wyściółki. Według wiedzy autorów opisano dotąd jedynie 10 takich przypadków. W pracy przedstawiono opis dwóch przypadków dużych, kiełbaskowatych wyściółczaków wewnątrztwardówkowych i zewnątrzrdzeniowych w części lędźwiowo-krzyżowej kanału kręgowego.

Słowa kluczowe: pierwotny, wewnątrztwardówkowy, zewnątrzrdzeniowy, wyściółczak.

of the spinal cord are rare; only 10 cases have been described in the literature. They are called primary tumours in this location as they do not have any connection with the central nervous system [2]. We describe two large sausage-shaped intradural extramedullary ependymomas in the lumbosacral area, the clinical presentations, surgical treatment, and a physiopathological hypothesis of this localization on the basis of the results of the present study and review of the literature.

Correspondence address: Dr. Pradipta Tripathy, Prof., Neurosurgery Department, IMS \& SUM Hospital, Kalinga Nagar, Bhubaneswar, Pin-751003, Odisha, India, phone: (M)-09439831761, (0)-0674-2386292, ext. 351, (R)-0674-2310970, fax: 0674-2386393, 0674-2386223,

e-mail: pradipta_tripathy@yahoo.com

Received: 24.02.2011; accepted: 15.03.2011 


\section{Case reports}

\section{Case 1}

A 24-year-old female was admitted with complaints of lower back pain for the last 3 years, bilateral lower limb numbness for the last 3 months, inability to move both lower limbs and being bedridden for the last 20 days. There was no bowel or bladder disturbance, and no history of trauma to the spine or fever in the recent past.

Her general physical examinations were normal. Her neurological examinations revealed grade 1 to 2 power in both lower limbs, and $50 \%$ loss of sensation to all modalities below T12 bilaterally. Deep tendon reflexes and plantar responses were absent bilaterally.

Magnetic resonance imaging (MRI) of the lumbosacral spine revealed a large intradural extramedullary sausage-shaped mass, measuring $17.6 \mathrm{~cm}$ (cranio-caudally) $\times 1.7 \mathrm{~cm}($ antero-posteriorly) $\times 2.1 \mathrm{~cm}$ (transversely), extending from the $\mathrm{T} 12$ to $\mathrm{S} 1$ vertebral level. The mass was isointense on $\mathrm{T} 1$-weighted image, isointense with scattered hyperintense foci on T2-weighted image (Fig. 1A), and post-contrast study showed intense enhancement of the mass (Fig. 1B).

There was no obvious calcification or haemorrhage but it was causing expansion of the spinal canal. The fi lum terminale and the nerve roots of the cauda equina were not visualized separately. A laminoplasty from T11 to S2 was done. On opening the dura, a large sausageshaped intradural extramedullary mass was seen extending from $\mathrm{T} 12$ to $\mathrm{S} 1$. The tumour was capsulated and could easily be separated from the conus and the nerve roots of the cauda equina. The roots and the filum appeared compressed and displaced laterally by the tumour. There was no invasion of filum terminale. It was a pale, pinkish red, highly vascular, firm mass. The tumour was excised totally and watertight dural closure was done. Immediately after the surgery, the patient experienced relief from her back pain, numbness disappeared and motor power in the lower limbs also showed improvement. By the time of discharge, the patient started walking with support. On a follow-up visit after 3 months she came walking without any support.

\section{Case 2}

A 21-year-old female was admitted with complaints of lower back pain for the last 1 year and pain radiating to both lower limbs for the last 3 months. There was no weakness, numbness in limbs or bowel and bladder disturbance. There was no history of trauma to the spine or fever in the recent past.

Her general physical examinations were normal. Her neurological examinations were also normal. The straight leg raising test was positive bilaterally at $<60$ degrees.

MRI of the lumbosacral spine revealed a large intradural extramedullary mass, measuring $7.8 \mathrm{~cm}$ (cranio-caudally) $\times 1.6 \mathrm{~cm}$ (antero-posteriorly) $\times 2 \mathrm{~cm}$ (transversely) extending from the L 3 to $\mathrm{S} 1$ vertebral level. The mass was isointense on T1-weighted image, isointense with scattered hyperintense foci on T2-weighted image (Fig. 2A), and post-contrast study showed intense enhancement of the mass (Fig. 2B). There was no obvious calcification or haemorrhage. The filum terminale and the nerve roots of the cauda equina are not visualized separately. She was operated on, and laminoplasty L3-S1 was done. On opening the dura, a large capsulated intradural extramedullary mass was seen extending from L3 to S1. The filum and the roots were compressed and displaced laterally by the tumour without any invasion. It was a pale, brownish grey, vascular, soft to firm mass easily separable from the filum and the nerve roots. The tumour was excised totally and watertight dural closure done. Immediately after the surgery, the patient experienced relief from her radiating pain. By the time of discharge the patient started walking with slight back pain. On a follow-up visit after 3 months she came walking without any pain.

\section{Histopathological examination}

In both cases the histopathological description was loosely textured tumour comprising small round to cuboidal cells separated by abundant eosinophilic hyaline, mucinous material in a background with microcystic change, interspersed blood vessels of variable size and few papillary structures, no definite ependymal rosettes, showing mild nuclear pleomorphism, insignificant mitosis and scant clear cytoplasm, consistent with myxopapillary ependymoma.

\section{Discussion}

Primary intradural extramedullary ependymomas of the spinal cord are extremely rare, in contrast to intramedullary ependymomas or ependymomas arising from the conus medullaris or filum terminale [2-5]. Occa- 

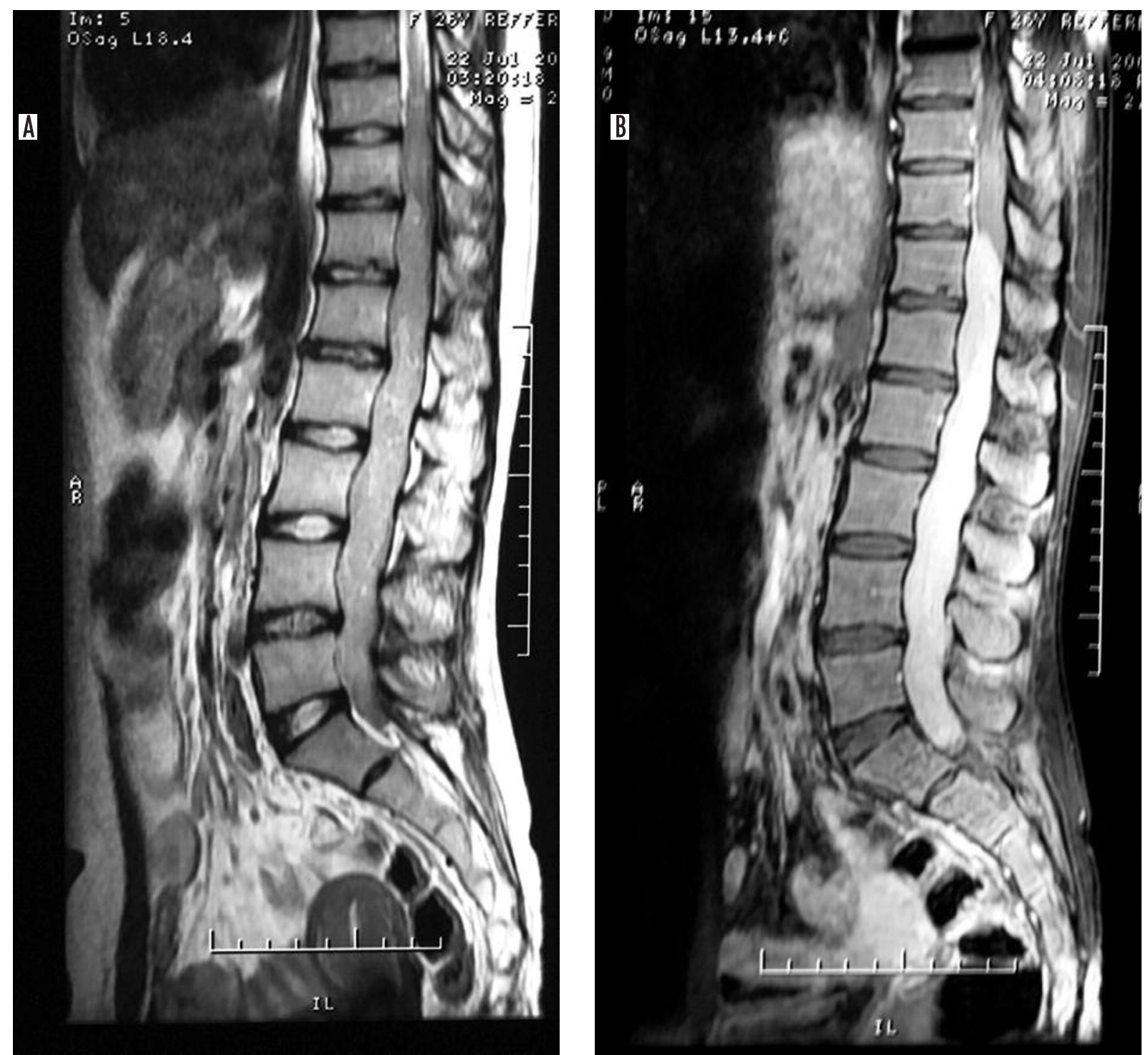

Fig. 1. Case 1: T2-weighted image of lumbosacral spine (sagittal view), showing an intradural extramedullary mass extending from T12 to S1 which is isointense with scattered hyperintense foci (A) and with intense enhancement of the mass after contrast injection (B)

sional cases of ectopic ependymoma outside the spine have been mentioned, developing in the subcutaneous tissue over the sacrococcygeal region, the mesovarium, the ovary, and the broad ligament $[2,6]$. The origin of intradural, extramedullary ependymomas is uncertain. They probably arise from heterotopic glial tissue pinched off from the neural tube during its closure $[2,6,7]$. In total, 10 cases are described in the literature. They mimic the clinical presentation and the radiographic characteristics of more common intradural extramedullary lesions such as neurinomas, meningiomas, or, rarely, arachnoid cysts $[2,4,8]$.
All cases reported in the literature concern women: the hypothesis of a hormonal mechanism playing a role in the development of the tumour was suggested by Duffau et al. [2]. A history of progressive medullary compression was usually reported [2]. In our patients, the symptoms were related to compression of the cauda equina.

In the literature, a thoracic location was found in 8 cases [2,3,7-9]. One cervical location [5], and an ependymoma arising from the L3 nerve root [6] were described as well. But in the present cases the tumour was located in the lumbosacral area. 

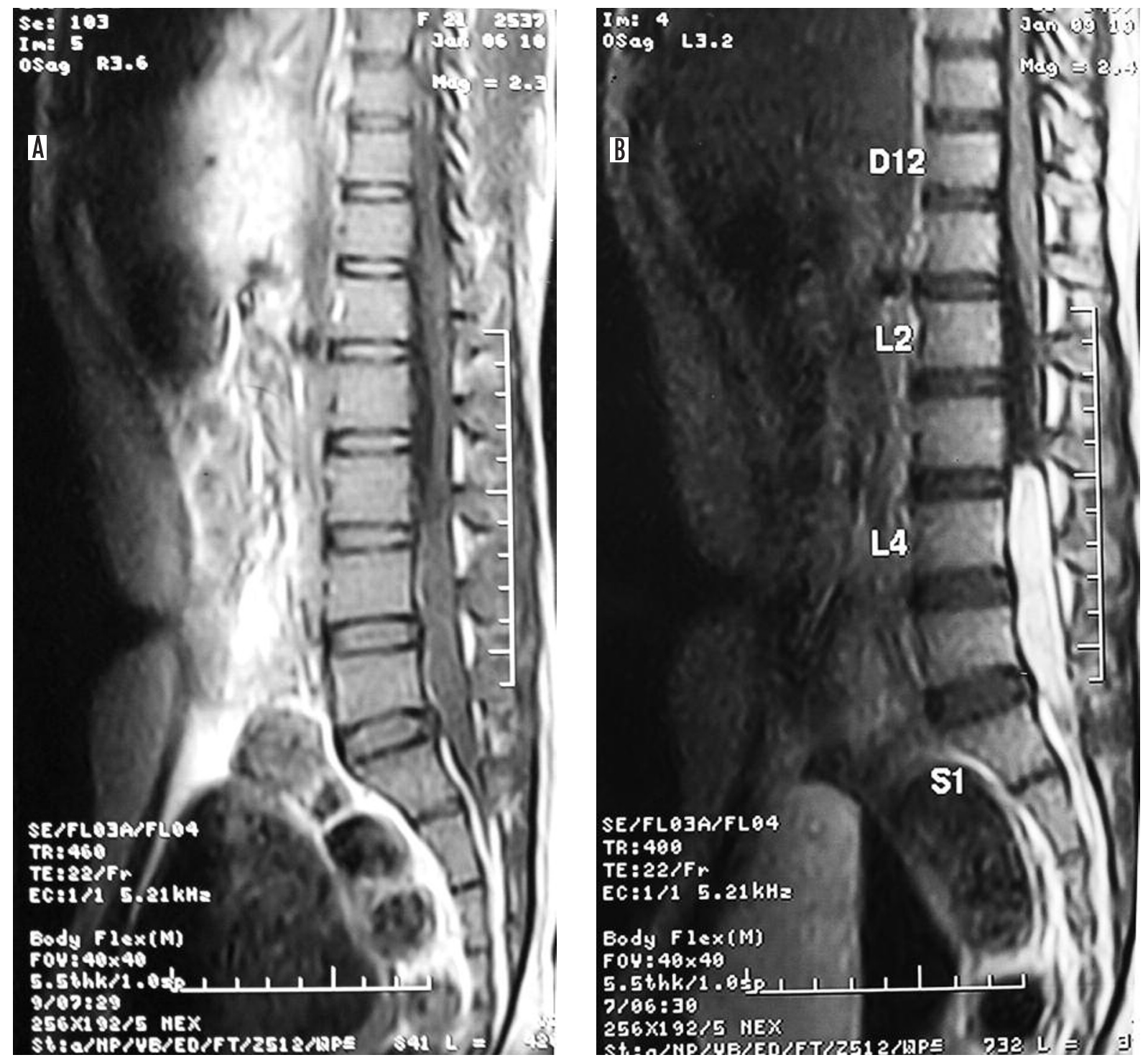

Fig. 2. Case 2: T2-weighted image of lumbosacral spine (sagittal view), showing an intradural extramedullary mass extending from L3 to S1 which is isointense with scattered hyperintense foci (A) and with intense enhancement of the mass after contrast injection (B)

The rare extramedullary ependymomas described in the literature were solid tumours showing an isointense signal on T1-weighted images and isointense with scattered hyperintense foci on T2-weighted images. Moreover, these tumours exhibited moderate to intense enhancement on contrast, very similar to meningiomas or neurinomas $[2,4]$. There was one case report of cystic thoracic intradural extramedullary ependymoma which radiologically mimicked an arachnoid cyst [8]. In the present cases, the masses were intradural extramedullary in location, isointense in T1-weighted image, iso- to hyperintense in T2weighted image, taking intense enhancement on contrast study. The tumours were encapsulated, easily separable from the surrounding cord or cauda equina, highly vascular, without any attachment to the cord, roots or dura mater.

The lack of connection between the lesion and the central nervous system excludes the hypothesis of exophytic ependymoma of the spinal cord [8-10]. An ependymal metastasis is equally unlikely due to the absence of any primary cerebral or medullary tumour. The probable origin of the ependymomas in this intradural extramedullary location in the present cases may be due to ectopic ependymal cells separated from the neural tube during its closure $[2,6,7]$. 
In the literature, no meningeal dissemination of an intradural extramedullary ependymoma has been reported [11]. Graça et al. reported one case of cystic thoracic intradural extramedullary ependymoma which had recurred twice in the same site, one month after the first surgery and three months after the second surgery [8]. The explanation given was that the recurrence was due to microscopic residual ependymoma or that residual lesions were hidden by compression of the spinal cord which could not be removed. Complete resection, if technically possible, and postoperative local radiation therapy for incomplete resection in case of malignant intramedullary ependymoma are recommended $[8,11]$.

In conclusion, primary intradural extramedullary ependymomas are rare tumours. They are called primary because of the lack of connection between them and the central nervous system. Unlike other intradural extramedullary lesions they usually have a benign course and can be excised totally.

\section{Disclosure}

Authors report no conflict of interest.

\section{References}

1. Baleriaux D.L. Spinal cord tumors. Eur Radiol 1999; 9: 1252-1258.

2. Duffau H., Gazzaz M., Kujas M., et al. Primary intradural extramedullary ependymoma: case report and review of the literature. Spine 2000; 25: 1993-1995.

3. Wolfla C.E., Azzarelli B., Shah M.V. Primary extramedullary ependymoma of the thoracic spine-case illustration. J Neurosurg 1997; 87: 643 .

4. Wagla W.A., Jaufman B., Mincy J.E. Intradural extramedullary ependymoma: MR-pathologic correlation. J Comput Assist Tomogr 1988; 12: 705-707.

5. Katoh S., Ikata T., Inoue A., et al. Intradural extramedullary ependymoma: a case report. Spine 1995; 20: 2036-2038.

6. Moser F.G., Tuvia J., LaSalla P., et al. Ependymoma of the spinal nerve root - case report. Neurosurgery 1992; 31: 962-64.

7. Payer M., Yonekawa Y., Imhof H.G. Solitary thoracic intradural extramedullary ependymoma. Clin Neurosci 1999; 6: 344-345.

8. Graça J., Gültali N., Haene D., et al. Cystic extramedullary ependymoma. Am J Neuroradiology 2006; 27: 818-821.

9. Cheng C.H., Lee T.C., Huang H.Y., et al. Extramedullary thoracic myxopapillary ependymoma: a case report. Ann Acad Med Singapore 1996; 25: 869-872.

10. Hentschel S.J., McCutcheon I.E., Ginsberg L., et al. Exophytic ependymomas of the spinal cord. Acta Neurochir 2004; 146: 1047-1450.

11. Lin Y.H., Huang C.I., Wong T.T., et al. Treatment of spinal cord ependymomas by surgery with or without postoperative radiotherapy. J Neurooncol 2005; 71: 205-210. 